Discussion Paper No. 16-005

Concentration on the Few?

R\&D and Innovation in

German Firms 2001 to 2013

Christian Rammer and Torben Schubert

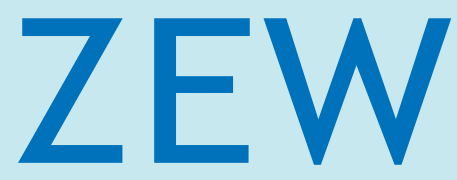

Zentrum für Europäische Wirtschaftsforschung $\mathrm{GmbH}$

Centre for European

Economic Research 


\section{Discussion Paper No. 16-005 \\ Concentration on the Few? R\&D and Innovation in German Firms 2001 to 2013}

Christian Rammer and Torben Schubert

Download this ZEW Discussion Paper from our ftp server:

http://ftp.zew.de/pub/zew-docs/dp/dp16005.pdf

Die Discussion Papers dienen einer möglichst schnellen Verbreitung von neueren Forschungsarbeiten des ZEW. Die Beiträge liegen in alleiniger Verantwortung der Autoren und stellen nicht notwendigerweise die Meinung des ZEW dar.

Discussion Papers are intended to make results of ZEW research promptly available to other economists in order to encourage discussion and suggestions for revisions. The authors are solely responsible for the contents which do not necessarily represent the opinion of the ZEW. 


\title{
Concentration on the Few? \\ R\&D and Innovation in German Firms 2001 to 2013
}

\author{
Christian Rammer ${ }^{\mathrm{a}}$, Torben Schubert ${ }^{\mathrm{b} *}$ \\ a Centre for European Economic Research (ZEW) \\ L 7, 1, 68161 Mannheim, Germany \\ ${ }^{\mathrm{b}}$ CIRCLE, Lund University, Sölvegatan 16, 22100 Lund, Sweden, and \\ Fraunhofer ISI, Breslauer Straße 48, 76135 Karlsruhe, Germany
}

January 2016

\begin{abstract}
Innovation activities in the German enterprise sector showed two opposing trends over the past two decades: While total innovation expenditures grew substantially, the number of firms conducting innovation activities fell sharply. Innovation expenditures hence concentrate on fewer firms. In this paper we analyse the evolution of firms' innovation and R\&D activities. Based on panel data from the German part of the Community Innovation Survey covering a 13 years period (2001 to 2013) we use continuous-time Markov-Chains to analyse the changing properties of the firms' choices to conduct $R \& D$ and non-R\&D innovation activities. Our findings are threefold. As compared to the pre-crisis period 2001-2007 there is a considerable change in innovation and R\&D behaviour of German firms from 2008 onwards with an increasing number of firms exiting R\&D and innovation activities. Smaller firms are the main driver behind this process, particularly with regard to quitting non-R\&D innovation activities. Although smaller firms were also less likely to move to higher levels of innovativeness and $R \& D$ engagement and more likely to fall back in the pre-crisis period, these trends have been more pronounced in the crisis and even in the post-crisis period. Both public innovation support and better financial capabilities can increase the rate chances to move to higher levels of innovativeness and reduce the chances to fall back.
\end{abstract}

JEL: O31, C22

* Corresponding author: Torben.Schubert@isi.fraunhofer.de

Phone: +49 7216809357 


\section{Introduction}

Innovation expenditures in Germany have increased at an impressive rate in the course of the last two decades. Between 1995 and 2013, businesses in Germany raised their spending for developing and introducing new products and new processes from $€ 60.8 \mathrm{bn}$ to $€ 144$.6bn giving a compound annual growth rate of $4.9 \%$ (Rammer et al. 2015). While these numbers suggest that German firms have become ever more focused on innovation, they hide the fact that this rise was mainly driven by large firms belonging to a few sectors. When we look at the above numbers by firm size we find that firms with less than 500 employees experienced only a very modest increase in their innovation expenditures (€25.7bn in 1995 vs. €34.5bn in 2013, i.e. 1.6\% per year) whereas large firms with more than 500 employees increased their spending from €35.1bn in 1995 to $€ 110.1 b n$ in 2013 (6.6\% per year). In line with these observations we also find a concentration of the activities on fewer firms. In particular, the share of innovators firms that have introduced at least one product or process innovation during the preceding three years - has similarly declined since the late 1990s. Having reached a peak in 1999 at 55.5\%, it dropped to $43.7 \%$ in 2007 and further declined to $37.1 \%$ in 2013.1

A look at the sector distribution conveys a similar concentration. In 1995, the R\&D intensive manufacturing sectors (pharmaceuticals, chemicals, electronics, machinery \& equipment, vehicles) spent €30.9bn on innovation and increased that figure to €92.6bn in 2013 (+6.3\% per year). Low-tech manufacturing and service sectors expanded their innovation expenditure by an average annual rate of $3.1 \%$

1 A similar decline in the innovation share is also found in other European countries, though changes in survey methodologies and the lack of annual surveys limit long-term comparisons. For 12 European countries reporting innovation data for all Community Innovation Surveys from 1996 to 2012, the share of innovators fell from $45 \%$ in 1996 to $40 \%$ in 2006 and went further down to $37 \%$ in 2012. 
These developments would not be problematic if they were due to firms from high-tech sectors growing at an above-average rate. While some well-known examples of this phenomenon also exist in Germany, e.g. the software company SAP, the absolute numbers of such cases is very limited. Moreover, the share of value added share of highly R\&D-intensive sectors remained fairly stable in Germany. This makes this explanation implausible.

In this article we argue that the phenomenon is more likely to be explained by smaller firms withdrawing from innovation activities at a large scale. Such a development would be of much greater concern because one of the pillars of the competitiveness of the German economy is seen in its highly innovative SMEs. A withdrawal of these firms from innovation would make the German economy considerably more reliant on set of well-known large companies, while grassroot innovation in SMEs may be lost. Moreover, since choices about innovation activities display a high degree of path dependence, these developments may easily turn permanent.

While the aggregate figures from above indeed provide initial evidence of SMEs withdrawing from innovation, such aggregate indicators can be misleading when processes simultaneously taking place are left unaccounted. More convincing evidence must therefore rely on firm level evidence using methods that can appropriately account for confounding factors. Relying on a panel of all firms that took part in the annual German Innovation Surveys covering the period from 2001 to 2013 we employ Markov Chain methods that model when and why firms change their innovative both in terms of actual innovation outcomes as well as in terms of R\&D effort.

The main are results are threefold. By dividing our data into two periods from 20012007 and 2008-2013, we show that the long-term share of firms engaging in innovation and $\mathrm{R} \& \mathrm{D}$ is considerably lower in the second period with an increase of the share of firms not innovative at all. Second, analyses of the determinants suggest that, as expected, smaller firms are more likely to quit innovation activities. We show that they are less likely switch to higher levels of innovative activities (e.g. from non-innovative to product or process innovator or from product or process innovator to simultaneous 
product and process innovator). They are also more likely to fall back to lower levels of innovativeness. Most importantly this pattern is becoming more pronounced in the later period of 2008 and after. Furthermore, we show that our findings are not a transitory short term shock of the economic crisis, because the declining trend persists even in 2011 and 2013, which were years of considerable economic growth in Germany. Thus, there seems a risk that these developments become persistent. We therefore analyse the effectiveness of a set of mechanisms potentially offsetting or at least slowing down these developments. We show that both public innovation support and better financial capabilities increase the chances to move to higher levels of innovativeness and reduce the probability to fall back. We conclude that strengthening public innovation support in in Germany should be a primary target of economic policy to avoid the risk of a permanent withdrawal of German SMEs from innovation.

\section{Background - persistence of innovation activities and its rela- tion to firm size}

Empirical accounts of firms' innovation activities usually indicate the existence of a core of systematically iinnovating firms surrounded by a larger number of firms conducting either no or only very sporadic innovation activities (Bottazzi et al. 2001, Cefis 2003, Malerba and Orsenigo 1997). Transition rates between the groups of innovation active and inactive firms are usually very low, which implies persistent heterogeneity of R\&D strategies across firms (Dosi 2007, see Crespi and Scelatto, 2015 and Latham and Le Bas, 2006 for an overview).

This persistence has often been explained with the reference to cumulative development of organizational routines driving innovation-relevant capabilitities (Nelson and Winter 1982; Teece et al. 1997). More precisely, a point is made that past innovation activities increase the effectiveness of future innovation activities making choices about innovation (or its absence) persistent and path dependent (see Nelson and Winter 1982). This persistence results on the one hand from the fact that by conducting innovation in the past, firms learn to manage innovation more effectively in the future. On the other hand, a firm's knowledge stock strongly determines its absorptive capacity and eases the ac- 
quisition of external knowledge, which provides another stimulus for innovation (Cohen and Levinthal 1990). In this respect, innovation is subject to increasing returns to scale ('success breeds success’, see Phillips 1971 and Mansfield 1968).

Persistence may also as a result of sunk costs (Peters 2009; Le Bas and Scelatto 2014). or if the factors driving a firm's decision to innovate or not are persistent over time. Market structure may be such a factor, i.e. firms acting in a highly competitive environment that demands regular innovative advance will tend to innovate continuously (see Schmookler 1966 for theoretical arguments and Malerba et al. 1997; Peters 2009; Woerter 2014 for empirical evidence).

In general, the theoretical predictions on the persistence of innovation activities have been corroborated by the empirical literature relying on a variety of different data sources. ${ }^{2}$

Máñez Castillejo et al. (2009, 2014) analysed persistency in R\&D for Spanish manufacturing firms and found that past $\mathrm{R} \& \mathrm{D}$ experience positively affected the decision to conduct $R \& D$, though the effect of prior $R \& D$ experience depreciates fairly quickly over time. Persistence seems to be driven both by sunk costs, success-breeds-success and demand-pull. Baraldi et al. (2013) find that persistence in R\&D depends on the market structure as only firms in oligopolistic markets (Schumpeter I industries) show persistent R\&D efforts. Woerter (2014) supports this finding based on Swiss data since persistence in R\&D expenditures is more likely for firms with few competitors.

Several studies use innovation survey data. They tend to focus on the output of innovative efforts, i.e. the introduction of new products and new processes, and the direct eco-

2 It should be noted however that studies using patent application data often found lower levels of persistence (Geroski et al. 1997; Cefis and Orsenigo 2001; Cefis 2003; Malerba and Orsenigo 1999). Although, Malerba et al. (1997) and Alfranca et al. (2002) find more evidence for persistence, particularly among larger firms and when looking at specific fields of technology, Duguet and Monjon (2004) conclude that persistency in patenting rather reveals persistency in technological leadership than in the decision to innovate. 
nomic outcome in terms of new product sales. These variables are generally found to be positively correlated over time (for Finland see Deschryvere 2014; for France see Duguet and Monjon 2004; Haned et al. 2014; Lhuillery 2014; for Germany see Peters 2009; Ganter and Hecker 2013; Hecker and Ganter 2014; for Luxembourg see Le Bas et al., 2015; Le Bas and Poussing 2014; for the Netherlands see Raymond et al. 2010; for Norway see Clausen 2012; Clausen and Pohjola 2013; for Sweden see Karlsson and Tavassoli 2015; Johansson and Lööf 2010; for the UK see Preverzer and Frenz 2013).

Another important data source is a panel survey of Spanish manufacturing firms containing information on innovation (see Máñez 2009, 2014; Martínez-Ros and Labeaga 2009; Triguero et al. 2014a,b; Triguero and Córcoles 2013). A few other authors use case study approaches (Matvejeva 2014), sometimes combined with firm survey data (Roper and Hewitt-Dundas 2008). Empirical studies for non-European countries are less frequent (see Huang 2008; Huang and Yang 2010; Jang and Chen 2011 for Taiwan; Rogers 2004 for Australia; Suárez 2014 for Argentina).

Accrodingly, the literature survey by Crespi and Scellato (2015) strongly supports the finding of persistency. Beyond that several studies show that the degree of persistence may depend on firm size.

This is because the well-documented increasing returns to scale in innovation (see Clausen and Pohjola 2013; Lhuillery 2014; Máñez et al. 2014; Raymond et al. 2010; Flaig and Stadler 1994) may be more pronounced for larger firms. In particular, because larger firms often possess complementary assets (Teece 1986) and follow more elaborated protection strategies of intellectual property (Neuhäusler 2012) necessary for privatizing the benefits of innovation, they are often more successful with their innovation activities.

This likely induces them to continuing their innovation activities. Empirical evidence of larger firms showing higher persistence is provided by Roper and Hewitt-Dundas (2008) and Antonelli et al. (2013). Also, larger firms follow more complex innovation strategies and more complex innovators are less likely to discontinue innovation (Le Bas and Poussing 2014). 
This suggests that any events potentially changing the firms' innovation behaviours (e.g. changes in the access to financing or demand side factors) are more likely to lead to changes in observed behaviour of small rather than large firms. While we do not endeavour to explain the reasons for the trend towards a concentration of innovation and $R \& D$ activities on a few firms, this also means that the concentration may be mainly driven by a withdrawal of smaller firms. Based on this, our first aim is to corroborate the already described trend of declining overall R\&D and innovation engagement in a setting controlling for various confounding factors, such as potential shifts in the sectoral composition. By this we intend to show that there was probably some change in the overall firms' innovation behaviour going on. Our second aim is to show that this trend was primarily driven by a withdrawal of small to medium-sized firms. Third, we aim to contribute to a better understanding of the options policy has to counteract a further concentration of innovation and R\&D on predominantly large firms. For this end we investigate the impact of specific firm characteristics on their likelihood to continue or discontinue innovation and R\&D. We start with the influence of public innovation subsidies as prime measure to increase and support firms' innovation and R\&D activities. Because the public innovation support is usually justified by either strengthening the ability to finance innovation or by bringing together complementary resources through innovation collaboration we also analyse the influence innovation collaboration and financial strength on the likelihood to continue or discontinue innovation and R\&D activities.

We now continue with a description of the underlying dataset and some more descriptive details on the dynamics of the R\&D and innovation engagement of German firms during the last 15-20 years. 


\section{Data}

\section{The Mannheim Innovation Panel}

Our study uses data from the German Innovation Survey which is part of the CIS initiative. In contrast to most other national CIS, the German Innovation Survey is an annual survey based on a panel sample. It is conducted by the Centre for European Economic Research (ZEW) on behalf of the Federal government. As ZEW is located in the city of Mannheim, this panel survey is called the Mannheim Innovation Panel (MIP). The MIP applies the common methodology of the CIS in terms of sampling, questionnaire and data quality control. It goes beyond the minimum requirements of the CIS in terms of size and sector coverage as it also includes very small firms (below 10 employees) and covers more service sectors than the core CIS service sector definition would require. The MIP questionnaire contains a number of additional questions not being part of the harmonised questionnaire of the CIS, including financial information and more detailed information on innovation processes and determinants, hence enlarging the analytical potential at the expense of imposing a higher response burden on the firms.

The MIP sample is a panel sample which was drawn in 1993 (for manufacturing) and 1995 (for services) and has been updated since every second year in order to compensate for panel mortality. While the sampling frame is the official business register, the register is not accessible for drawing a sample. Instead, the firm data base of Creditreform, Germany’s largest credit rating agency, is used. This data base includes all economically active enterprises in Germany and hence includes the same firm population as the business register. An advantage of using Creditreform's data base for sampling is the opportunity to add further information to the data, including the credit rating of each firm. We use this opportunity in the present paper.

Rammer and Peters (2013) provide a comprehensive overview of this survey and its panel structure, including a discussion of the persistence of innovative activities. The current sample size is around 35,000. As the MIP is a voluntary survey, and owing to the high response burden due to the lengthy questionnaire, response rates are compara- 
bly low at 25 to 35\%. The panel consists of 5,000 to 8,000 firm observations per year based on questionnaire responses. In addition, a large-scale non-response survey of a similar size is conducted every year to control for a likely response bias with respect to $\mathrm{R} \& \mathrm{D}$ activity and the introduction of product and process innovation. The non-response survey is conducted through a telephone interview, using exactly the same definitions and questions as used in the questionnaire. For this paper, we use both the R\&D and innovation information from the questionnaire and the non-response interviews.

\section{Descriptive Statistics on Firms Conducting R\&D and Innovation Activities}

For this paper, we use data for the period 2001 to 2013. We start in 2001 for methodological reasons since the question on product and process innovation has been redesigned in that year, causing a break in data (with a higher share of firms reporting both product and process innovation prior to the re-design). Within the 13 year period covered in this study, a total of 49,557 different firms have been part of the sample. 42,247 firms responded at least one time. $36.8 \%$ of the firms where part of the sample at the beginning of the period (and hence have the chance to appear in every single year of the period under cover) while the others entered the sample in later years (between 8 and $12 \%$ for each of the reference years in which the panel sample had been refreshed: 2002, 2004, 2006, 2008, 2010 and 2012). The total number of responses by the 42,247 firms is 153,224 , giving an average number of responses per firm of 3.6. As usual in voluntary firm panel surveys with high panel mortality, the panel is strongly unbalanced. Only $0.7 \%$ of the firms in our sample responded in each of the 13 years, producing $2.5 \%$ of all firm-year observations. $30 \%$ of the firms responded at least 5 times during the period 2001-2013, producing 62\% of all observations. Table 1 provides details on the panel structure of our sample. 
Table 1: Number of firms and firm-year observations differentiated by the number of panel participations during 2001 and 2013

\begin{tabular}{lrrrr}
\hline $\begin{array}{l}\text { No. of panel } \\
\text { participations }\end{array}$ & No. of firms & $\begin{array}{r}\text { Share in all } \\
\text { firms (\%) }\end{array}$ & $\begin{array}{r}\text { No. of firm-year } \\
\text { observations }\end{array}$ & $\begin{array}{r}\text { Share in all } \\
\text { observations (\%) }\end{array}$ \\
\hline 1 & 13,300 & 31.5 & 13,300 & 8.7 \\
2 & 7,541 & 17.8 & 15,082 & 9.8 \\
3 & 4,961 & 11.7 & 14,883 & 9.7 \\
4 & 3,764 & 8.9 & 15,056 & 9.8 \\
5 & 2,738 & 6.5 & 13,690 & 8.9 \\
6 & 2,481 & 5.9 & 14,886 & 9.7 \\
7 & 2,129 & 5.0 & 14,903 & 9.7 \\
8 & 1,609 & 3.8 & 12,872 & 8.4 \\
9 & 1,274 & 3.0 & 11,466 & 7.5 \\
10 & 975 & 2.3 & 9,750 & 6.4 \\
11 & 657 & 1.6 & 7,227 & 4.7 \\
12 & 525 & 1.2 & 6,300 & 4.1 \\
13 & 293 & 0.7 & 3,809 & 2.5 \\
\hline Total & 42,247 & 100.0 & 153,224 & 100.0 \\
\hline
\end{tabular}

Table 2 gives some descriptive results on the persistence of R\&D and innovation activities. Following the standard measurement of in-house R\&D activities in the CIS, we distinguish continuous, occasional and no R\&D. Innovation activities are separated by product and process innovation. When calculating the share of firms that reports the same $R \& D$ or innovation status in each year of survey participation, we see that the share falling with the number of participations up to about 8 participations. For firms with very frequent responses to the survey, this share does not vary significantly. Among the firms participating in each of the 13 years covered by this study, 39\% reported the same status in terms of product innovation (i.e. either no product innovation in each year, or product innovation in every single year) and 36\% reported the same status in terms of process innovation. For continuous R\&D, the share of firms with persistent activities is much higher (66\% reporting either continuous R\&D activities in every single year, or never had continuous $R \& D$ activities in any of the 13 years) as is the share of firms with respect to occasional $R \& D$ (57\%) and no $R \& D(56 \%)$. One should note that the persistence of R\&D and innovation activities in CIS-type surveys 
will be overrated owing to the fact that both $R \& D$ and innovation activities reported in a certain survey year should theoretically refer to activities in the previous three year period. In practice, many firms do not seem to follow these instructions but rather report activities for the reference year only. This finding is supported both by cognitive testing of CIS survey questions, face-to-face interviews with enterprises participating in the survey and panel survey results that show responses inconsistent with the three year reference period (see Rammer and Peters, 2013, for more details).

Table 2: Persistence of $R \& D$ and innovation activities differentiated by the number of panel participations during 2001 and 2013

\begin{tabular}{lrrrrr}
\hline $\begin{array}{l}\text { No. of panel } \\
\text { participations } \\
\text { during 2001 and } \\
2013\end{array}$ & $\begin{array}{r}\text { Share of firms not changing their status with respect to ... } \\
\text { product } \\
\text { innovation }\end{array}$ & $\begin{array}{r}\text { process } \\
\text { innovation }\end{array}$ & $\begin{array}{r}\text { continuous } \\
\text { R\&D }\end{array}$ & $\begin{array}{r}\text { occasional } \\
\text { R\&D }\end{array}$ & no R\&D \\
\hline 1 & 100 & 100 & 100 & 100 & 100 \\
2 & 75 & 72 & 87 & 84 & 83 \\
3 & 62 & 57 & 74 & 71 & 72 \\
4 & 53 & 48 & 69 & 63 & 62 \\
5 & 46 & 38 & 64 & 56 & 54 \\
6 & 44 & 36 & 61 & 54 & 52 \\
7 & 41 & 34 & 59 & 52 & 53 \\
8 & 36 & 28 & 57 & 48 & 47 \\
9 & 39 & 28 & 57 & 47 & 47 \\
10 & 37 & 29 & 57 & 47 & 50 \\
11 & 35 & 25 & 54 & 43 & 48 \\
12 & 38 & 29 & 59 & 51 & 52 \\
13 & 39 & 36 & 66 & 57 & 56 \\
\hline
\end{tabular}

When calculating the share of firms with $R \& D$ and innovation activities over the 13year period using sample weights (corrected for a likely non-response bias, see Aschhoff et al., 2013, for more details), one can observe a distinct downward trend for the share of firms having introduced product or process innovation, going down from 52\% in 2001 to $37 \%$ in 2013. For continuous R\&D we find much smaller decrease (from $14 \%$ to $12 \%)$. The share of firms with occasional $R \& D$ is fluctuating somewhat stronger but also shows a downward trend (from 10\% to 8\%). When expanding the observation 
period back to the mid 1990s, the decrease in the share of innovating firms becomes even more salient while the share of firms with continuous or occasional R\&D was lower in the mid 1990s than in 2013.

The falling share of firms with $R \& D$ and innovation activities is sharply contrasted by a strong and almost steady increase in total innovation expenditure in the German enterprise sector over the past two decades. Though the data are nominal values, the average annual rate of growth rate of $4.0 \%$ (2001-2013) indicates a strong real growth of innovation budgets. Broken down by size classes one clearly sees that large enterprises were mainly responsible for that increase (4.9\% average annual growth) while small and medium-sized firms have expanded their innovation expenditure at an annual rate of $1.8 \%$ only. These two opposing trends motivate our empirical study.

Figure 1: Innovation and R\&D activities, and innovation expenditure in the German business enterprise sector, 1995-2013
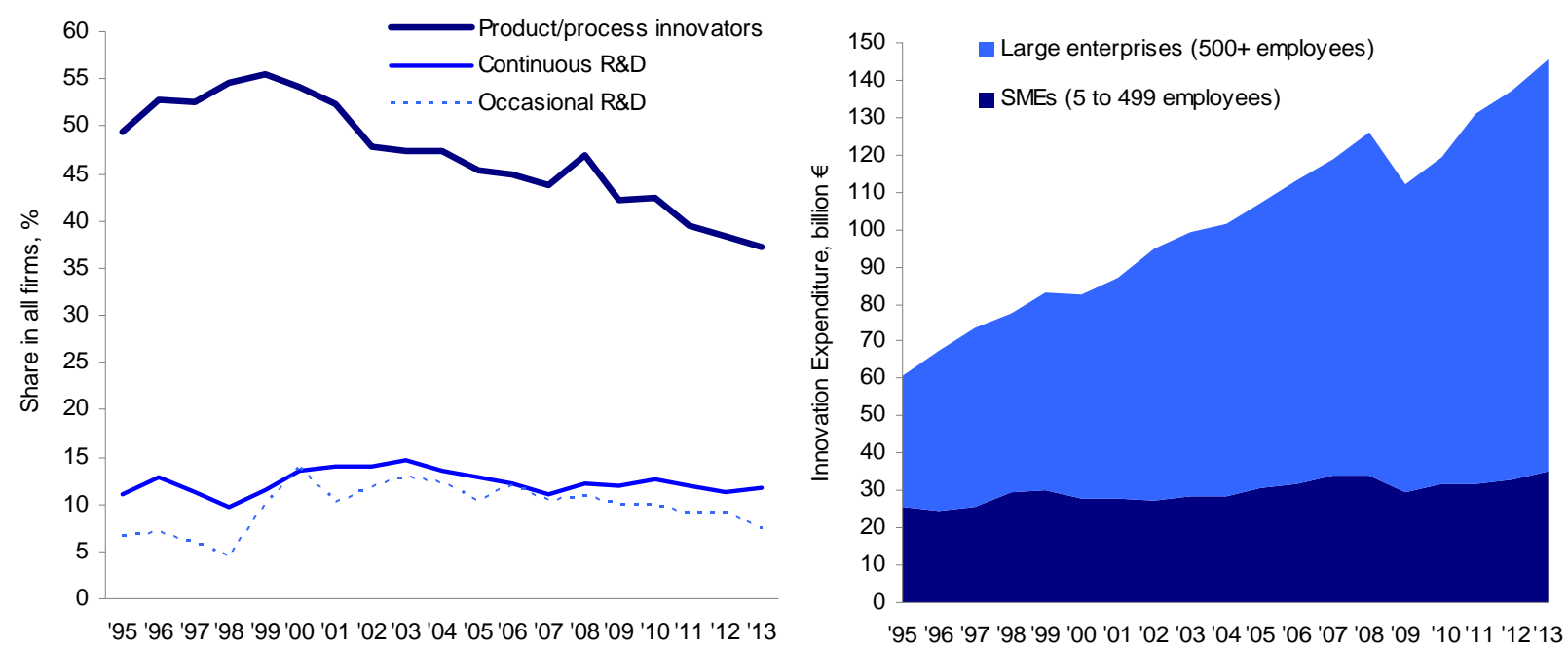

Note: weighted results. 


\section{Methodology}

\section{An Introduction to Markov Chains}

In order to analyse our main research questions (see Section 2) we make use of a set of econometric Maximum Likelihood estimators that belong to the class of Markov Chain Models. Markov Chains are so called state-space models, which describe how observed units move between a fixed (though possibly large) set of discrete states. Focusing on the innovation state, on the input side we will distinguish between different states of R\&D engagement - specifically “no R\&D”, “occasional R\&D” and “continuous R\&D”. On the output-side we will consider three states of innovation engagement: "no innovations”, "product or process innovations”, and "product and process innovations”.

To facilitate the exposition of the methodology, we refer to the R\&D model in the following. The three states constitute the state space. As we have panel data at hand, we can construct two pieces of information. The first is the so-called starting vector ${ }^{3}$

$$
p_{0}=\left(\begin{array}{lll}
p_{10} & p_{20} & p_{30}
\end{array}\right)
$$

which simply contains the probabilities in the starting period that a firm was in state 1 (e.g not R\&D active), state 2 (occasionally R\&D performing) or in state 3 (continuously R\&D performing), where each firm must be in exactly one state.

The second piece of information that can be gathered from the panel data is on how firms move between the states over time. This information is usually represented in the

3 Technically we will use a somewhat more complicated model than the one described above in two respects. First we allow for time to pass continuously and second we allow the transition probabilities to depend on firm-specific covariates in all our analyses. But to facilitate the presentation of the methodology we will continue with the time-discrete model because it is easier to understand while the general mechanics are identical. We also defer the discussion of the firm specific covariates even though they are already used as controls in predicting the stationary distributions, which we now turn to. 
transition matrix which contains in each cell $(i, j)$ the probability that a firm moves from state $i$ to state $j$. With three states it looks as follows:

$$
P=\left(\begin{array}{lll}
q_{11} & q_{12} & q_{13} \\
q_{21} & q_{22} & q_{23} \\
q_{31} & q_{32} & q_{33}
\end{array}\right)
$$

The diagonal elements will then obviously indicate the probabilities that a firm will remain in the current state indicating the degree of persistence. In the transition matrix all rows must sum to one, since each firm attached to one particular state must either stay there or move to one of the other states. Furthermore it is worth noting that panel data allows estimating the transition matrix by calculating the shares in which a firms from each state $i$ transited to any of the states $j$.

Markov Chains can be used for a variety of purposes. For example Tavassoli and Karlsson (2015) calculate Eq. (2) for different combinations of innovations and argue for heavy persistence in firms' innovation behaviour based on the observation that the diagonal probabilities are much larger than the off-diagonal probabilities.

Further, under the Markov assumption that the current state of the system is only determined by its directly preceding states, Eq. (1) and Eq. (2) can also be used for prediction .In particular, the k-periods-ahead prediction at time $t$ is simply:

$$
p_{t+k}=p_{t} \cdot P^{k}
$$

\section{Predicting Stationary Distributions}

Eq. (3) is particularly interesting because it allows an assessment of the future distributions of firms between the different innovation and R\&D engagement classes. In particular, it can be shown that under certain conditions ${ }^{4}$ the future distribution in Eq. (3)

$4 \quad$ We will not state these properties here but they are true in our application. 
converges to a constant limit. This is called the stationarity property and states that the long-run distribution does not depend on the starting vector. It can be shown that the stationary distribution for three states is determined by the following formula:

$$
p=\left(\begin{array}{l}
1 \\
1 \\
1
\end{array}\right)^{\prime}\left(\left(\begin{array}{lll}
1 & 0 & 0 \\
0 & 1 & 0 \\
0 & 0 & 1
\end{array}\right)-\left(\begin{array}{lll}
q_{11} & q_{12} & q_{13} \\
q_{21} & q_{22} & q_{23} \\
q_{31} & q_{32} & q_{33}
\end{array}\right)\left(\begin{array}{lll}
1 & 1 & 1 \\
1 & 1 & 1 \\
1 & 1 & 1
\end{array}\right)\right)^{-1}
$$

In principle we use this formula in Section 5 when we calculate the stationary distributions to evaluate whether the innovation behaviour of German firms has changed over time. In particular, we will compare the stationary distributions implied in the before crisis period (2001-2007) in the crises period (2008-2010) and the post crisis period $(2011-2013) .5$

\section{Firm-specific Transition Probabilities}

Our second aim is to assess whether small and medium-sized firms are responsible for the decline in the observed innovator and R\&D-performer rates. Our third aim is to analyse, whether the fact that a firm received public funding, was involved in innovation collaborations, or was financially restricted has any consequences on the decision to move in or out of innovation and R\&D. To analyse these questions we have to allow the probabilities in Eq. (2) to depend on firm characteristics. A convenient functional form is the hazard rate specification also used in other survival models:

$$
q_{i j}\left(x_{h t}\right)=q_{i j}^{b} \mathrm{e}^{x_{h t} \beta_{i j}}
$$

5 As indicated we have actually used estimates of the transition matrix that are based on size and sector controls. We evaluate the stationary distributions for the mean of the control variables. Since the means are calculated over the whole sample period, the results are more robust to changes in the sample composition than to use unconditional models. 
where $i$ and $j$ denote states as before, $h$ indicates a firm, and $t$ the time period. $q_{i j}^{b}$ is a baseline hazard of moving from $i$ to $j$, which is modified according to an exponential function that depends on firm characteristics $x_{h t}$ and parameters $\beta_{i j}$. While maximization occurs over the baseline hazard and the parameter $\beta_{i j}$, it should be noted that the main interest is on the latter, since they indicate whether the actual transition probability for a firm with particular characteristics is below or above the baseline hazard. In Section 5 we will therefore report the hazard rate which represents the percentage increase or decline of the baseline hazard due to a marginal increase of the explanatory variables.

For all estimations we have used the msm-package for $\mathrm{R}$, which was provided by Jackson (2011).

\section{Main Variables}

Markov Chains in its easiest form only need information on the state space and how units change between states. Thus the most important variables are those that define the state space. As indicated before we use a variable for innovation input (conducting R\&D activities) and innovation output (having introduced a product or process innovation).

As concerns the $R \& D$ variable, firms are asked to report whether they perform $R \& D$ on an occasionally or on a continuous basis or whether they do not have in-house $R \& D$ activities. These three answers determine the three states that firms may move between. With respect to the innovation output there is information on whether firms have introduce no innovation in the last three years, whether they introduced product innovations or whether they introduced process innovations. From these answers we construct a three state variable, which is zero if the firm was not an innovator. It is equal to 1 , if the firm introduced either product or process innovations, and equal to 2, if it introduced product or process innovations simultaneously. This definition was chosen because the states 1,2 , and 3 can be though of as reflecting increasing engagement in innovation and R\&D, with 1 indicating no engagement, 2 indicating intermediate engagement, and 3 high engagement. 
The second set of variables consists of those that are used to allow for firm-specific differences in the transition probabilities. In order to control for sector differences we use the OECD tech-level classification to differentiate between medium- high-tech sectors, medium-low-tech sectors, and services. We will refrain from interpreting these variables as they are merely treated as potential confounders. More interesting are the variables on size of the firm as we have discussed that smaller firms might be more at the core of a potential reduction in the share of firms engaged in innovation and $\mathrm{R} \& \mathrm{D}$. In order to investigate how the baseline hazard is affected by size of the firm we include a dummy for small and medium sized companies (1-499 employees). ${ }^{6}$ The baseline category consists of firms with more than 500 employees. Finally we include a set of variables that are commonly discussed as promoters of innovation. One variable measures whether the firm received public support for R\&D or innovation by any public funding body inside or outside Germany (State governments and Federal government in Germany, EU, other national or international sources). The second is equal to 1 if the firm was active in innovation partnerships to analyse the importance of the social framing and bidirectional knowledge flows between firms. The third measure is a measure of the firm's financial strength. We use the credit rating index of Creditreform. The index is a continuous variable takes the value of 1 for firms with the best rating and 4 with the lowest. Firms in the state of insolvency or bankruptcy get index values 5 or 6 . We invert this measure in order to let larger values denote a better credit rating in order to facilitate interpretation of the coefficients.

6 We further differentiate between firms that have below 50 employees, those that have between 50 and 249, and those that have 250 and 499. Technically it would have been possible to include a continuous measure of size (e.g. number of employees) with this would have hidden any differences between the classes of the firm. 


\section{Results}

\section{Stationary Distributions of R\&D and Innovation Activities}

Going beyond the descriptive accounts of the aggregated share of firms conducting innovation and R\&D activities, in this section we are particularly interested predicting the long-term evolution of distribution of the firms between the different innovation and $\mathrm{R} \& \mathrm{D}$ states in the long-run. This generalises the descriptive findings of the aggregate data (Section 3) in one important respect. In particular, investigating actual shares only gives information on the contemporary distribution. Analysing stationary distributions implied by actual transition rates gives information on the long-run distribution. Thus the analysis becomes forward-looking.

We intend to show that the transition matrices in earlier sub-periods of dataset implied stationary distributions with higher innovation and $R \& D$ engagement than in later periods. For this end we subdivide our dataset in a pre-crisis period ranging from 20012007, a crisis-period from 2008-2010 and a post-crisis period from 2011 to 2013. Differentiating between a crisis and post-crisis period is primarily done to ensure that the declining trends are not only driven by short-term transitory shock of the economic crisis in 2008-2010. Instead by showing that the trends also extend to the period 20112013 characterised by a positive economic climate, we intend to demonstrate that the concentration trend is permanent and unlikely a pure business cycle effect. The results can be found in Figure 2.

Looking at the left panel we observe a clear pattern, which can be described by a continuous increase in the share of non-R\&D active firms over the three periods, a slightly decreasing share of firms that occasionally conduct R\&D, and a strongly contracting share of firms that continuously do so. This effect is not negligible. While the stationary share of continuous R\&D performers was still about 28\% in 2001-2007, this share drops 19\% in 2011-2013. This corresponds to a relative decline of almost one third. As concerns occasional R\&D the drop is more modest (from $15 \%$ to slightly below $14 \%$ ). Because each firm must be in exactly one state, corresponding to the reduction of the 
shares of $R \& D$ active firms we observe an increase of the non- $R \& D$ active firms from $57 \%$ in the pre-crisis period to $67 \%$ in the post-crisis period.

A point of great concern is that these changes cannot easily be interpreted as a crisisinduced pro-cyclical phenomenon because instead of returning to the pre-crisis distribution also in the period 2011-2013 (a period of economic prosperity in Germany) the negative trends seem to amplify even after the crisis.

Figure 2: The stationary distributions of the share of firms conducing R\&D (top panel) and innovation (bottom panel) in pre-crisis and post-crisis periods
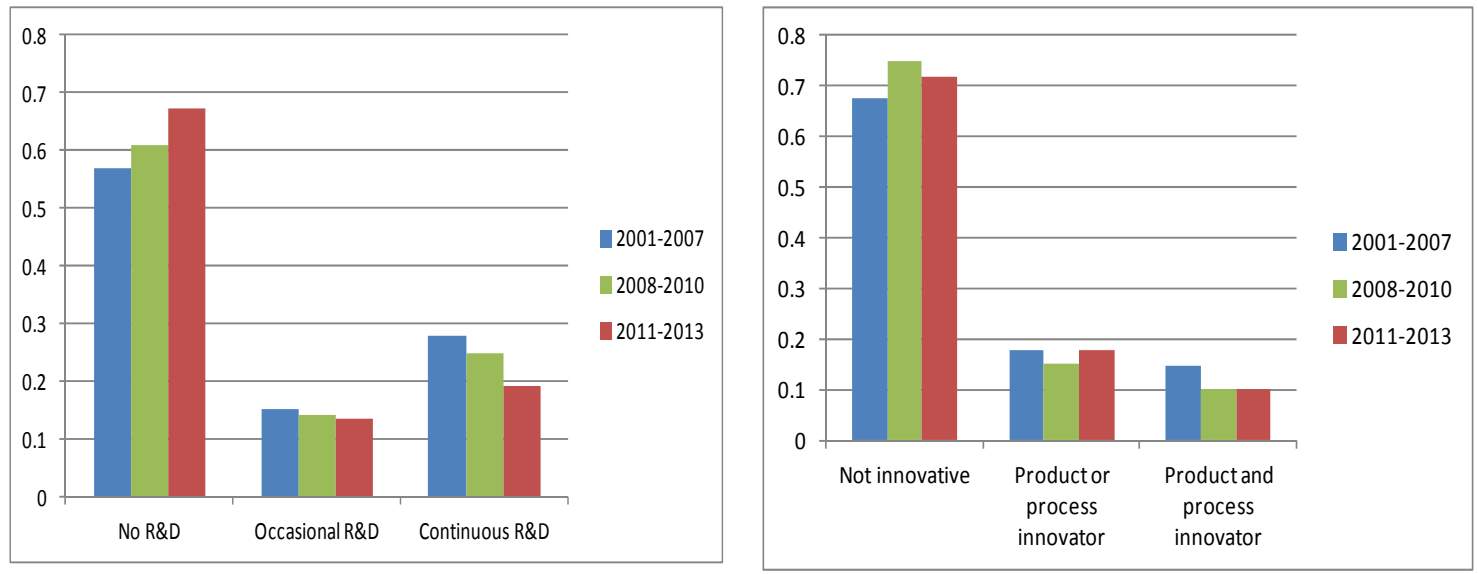

The results for introducing product and process innovations are similar, albeit a little bit less drastic. The share of simultaneous product and process innovators drops from $15 \%$ to $10 \%$, which again corresponds to $33 \%$ relative decrease. The share of product or process innovators stays with about $18 \%$ roughly constant, while the non-innovators increase from $67 \%$ to $72 \%$. In one important respect these results differ from changes in the stationary $R \& D$ distributions. In particular, while the negative trend intensified for $R \& D$, there seems a slight trend back towards the pre-crisis values for innovation participation at least for the stationary shares of non-innovating firms and product or process innovators.

In summary, we make two important observations. First, firms in Germany retract both in terms of innovativeness and in terms of R\&D participation. This corroborates the 
findings from aggregate descriptive accounts also in a setting where a number of control variables (e.g. sector composition or size) are included. Thus, there is evidence against the argument that changing industry structures or firm growth of particularly innovative firms can completely explain the concentration trends. Second, given that both for R\&D and innovation the trends are not reversed after the crisis - there is even intensification for R\&D - the transience of these trends can be doubted implying that business cycle events are unlikely to be the main cause. This suggests that a change in the behaviour of firms than a change in the composition of the sample has occurred driving these observations. In the following, we analyse whether small firms have contributed to this trend in particular. After that we analyse whether there are conceivable policy measures to mitigate the decline in the share of R\&D and innovation performing firms.

\section{Changing Transition Probabilities and Their Relation to Firm Size}

The aggregate figures on innovation expenditures suggest that there is a strong concentration on large firms, implying that the declining trend in innovation and R\&D engagement is driven by smaller rather than larger firms. We intend to corroborate this view now in setting controlling for confounding factors such as those resulting from changes in sector compositions or growth dynamics of particularly innovative firms.

We start by considering baseline models, in which we analyse whether and how the dynamics between the innovation (non-innovating, product or process innovator, product and process innovator) and $R \& D$ states (non $R \& D$ active, occasional $R \& D$, continuous R\&D) are different for firms in differing size groups. The results can be found in Table 3.7

7 The coefficients represent hazard rates, indicating how a variable affects the likelihood of any particular state change as compared to the baseline hazard. For example, the coefficient of 0.5209 for the SME (1-499) variable as concerns the entry S1S2 should be interpreted that an SME with 1-499 employees is $37.91 \%(=100-52.09)$ less likely to move from non-R\&D-active to occasional R\&D activities as compared to the baseline of large firms (500+ employees). 
Table 3: Transitions probabilities as function of firm size

\begin{tabular}{|c|c|c|c|c|}
\hline & $\begin{array}{c}R \& D \\
\text { hazard rate }\end{array}$ & $\begin{array}{l}\text { Innovation } \\
\text { hazard rate }\end{array}$ & $\begin{array}{c}R \& D \\
\text { hazard rate }\end{array}$ & $\begin{array}{l}\text { Innovation } \\
\text { hazard rate }\end{array}$ \\
\hline \multicolumn{5}{|c|}{ SME (1-499) } \\
\hline S1S2 & $0.5209 * * *$ & $0.5934 * * *$ & & \\
\hline$S 2 S 1$ & $0.8952 * *$ & $1.4354 * * *$ & & \\
\hline S2S3 & $0.7519 * * *$ & $0.7873 * * *$ & & \\
\hline S3S2 & $2.2793 * * *$ & $2.4985 * * *$ & & \\
\hline \multicolumn{5}{|c|}{ SME (1-50) } \\
\hline S1S2 & & & $0.3841 * * *$ & $0.5474 * * *$ \\
\hline$S 2 S 1$ & & & $0.8062 * *$ & $1.8210 * * *$ \\
\hline S2S3 & & & $0.6928 * * *$ & $0.7311 * * *$ \\
\hline S3S2 & & & $3.3195 * * *$ & $3.7000 * * *$ \\
\hline \multicolumn{5}{|c|}{ SME (50-249) } \\
\hline S1S2 & & & $0.5422 * * *$ & $0.7444 * * *$ \\
\hline$S 2 S 1$ & & & $0.8252 * *$ & $1.6027 * * *$ \\
\hline S2S3 & & & 0.9189 & $0.8492 * * *$ \\
\hline S3S2 & & & $3.1651 * * *$ & $3.1299 * * *$ \\
\hline \multicolumn{5}{|c|}{ SME (250-499) } \\
\hline S1S2 & & & $0.7184 * * *$ & 0.9439 \\
\hline$S 2 S 1$ & & & 0.8906 & $1.4532 * * *$ \\
\hline S2S3 & & & $1.2001 * *$ & 0.9483 \\
\hline S3S2 & & & $2.5214 * * *$ & $2.3449 * * *$ \\
\hline \multicolumn{5}{|c|}{ MML (500-1000) } \\
\hline S1S2 & & & $0.7457 * * *$ & 1.0702 \\
\hline$S 2 S 1$ & & & 0.8407 & $1.3628 * * *$ \\
\hline S2S3 & & & 1.1266 & 1.0188 \\
\hline S3S2 & & & $1.8689 * * *$ & $1.8166 * * *$ \\
\hline \multicolumn{5}{|c|}{ Med. high-tec man. } \\
\hline S1S2 & $2.1267 * * *$ & $1.7893 * * *$ & $2.1352 * * *$ & $1.7671 * * *$ \\
\hline S2S1 & $0.6169 * * *$ & $0.5753 * * *$ & $0.6244 * * *$ & $0.5910 * * *$ \\
\hline S2S3 & 1.0505 & 1.0084 & 1.0457 & 0.9957 \\
\hline S3S2 & $0.4997 * * *$ & $0.7066 * * *$ & $0.5306 * * *$ & $0.7442 * * *$ \\
\hline \multicolumn{5}{|c|}{ Med. low-tech. man. } \\
\hline S1S2 & $1.3279 * * *$ & $1.2451 * * *$ & $1.3521 * * *$ & $1.2479 * * *$ \\
\hline$S 2 S 1$ & $0.7272 * * *$ & $0.9146 * * *$ & $0.7375 * * *$ & $0.9405 * *$ \\
\hline S2S3 & $0.8863 * * *$ & 1.0298 & $0.9022 * * *$ & 1.0288 \\
\hline S3S2 & 0.9723 & $0.9053 * * *$ & 1.0669 & 0.9580 \\
\hline $\mathrm{N}$ & 126891 & 183774 & 126891 & 183774 \\
\hline $\mathrm{T}$ & 13 & 13 & 13 & 13 \\
\hline LR-test & $80108.63 * * *$ & $10015.46 * * *$ & $80792.82 * * *$ & $10996.39 * * *$ \\
\hline
\end{tabular}

What we see is that SMEs are approximately $37 \%$ less likely to become occasional $R \& D$ performers if they had not performed R\&D before. However, they appear somewhat less likely (about 10\%) to fall back to no R\&D activities, if they were occasional $R \& D$ performers. Thus, on the lower ranks of $R \& D$ activities smaller firms appear to switch states less often. Given, in any case that the hazard rate for staying non-R\&D active (0.52) is much smaller than the hazard rate for falling back to no R\&D activities (0.89), the net dynamics will contribute to a higher likelihood to end up as non-R\&D performing in the long run. Additionally, they are $25 \%$ less likely to develop continuous 
R\&D activities and are $127 \%$ more likely to abandon continuous in favour of occasional R\&D. Comparable results can be found for innovation. SMEs are both with respect to state changes from no to product or process and from product or process to product and process innovations less likely to move upward and more likely to move downward. The hazard rates indicate that also here the effects are quite sizeable in particular with respect to risk to falling back from very broad innovation activities (increase of almost $150 \%$ as compared to large firms).

To probe this result we subdivide SME dummy into the groups 1-49 employees, 50-249 employees, and 250-499 employees. We also allow an additional dummy for medium to medium-large companies (500-999 employees) which are of particular importance to the German economy. Basically these findings corroborate the results showing that although the patterns are strongest for the smallest firms and gradually become weaker as firm size increases, they do not die out completely for any of the groups. Thus even for the group of firms with 500-999 employees we can still determine patterns that hint to an increase for risk of falling back to lower and lower chances to move to higher categories.

This finding is interesting in itself because it unveils the dynamics that explain a concentration of R\&D and innovation activities on large firms. However, it does not explain that this concentration is increasing. For this we have to show those patterns became more pronounced over time. This is done in Table 4, where we allow hazard rates for the corresponding to the SME dummy to differ by time period. Following the distinction pre-crisis, crisis, and post-crisis-period (see Figure 2), we analyse this using two comparisons. In the first, we include a time dummy for the compound crisis and postcrisis period 2008-2013 and in the second we include a dummy for the post-crisis period only. In either case, if the hypothesis is correct that the decline in the share of firms performing innovation and R\&D is due to a changing behaviour of SMEs, the interaction of the SME variable with these dummies should indicate an excess decrease (values smaller 1 ) in the hazards to move to broader innovation or more continuous $R \& D$ and an excess increase (values larger 1 ) in the risk to fall to lower categories. 
In particular for $R \& D$, this pattern can be clearly found for both time periods and, in line with Figure 2 is it particularly strong for the period 2011-2013. Firms are less likely to move to higher occasional $R \& D$ if they were not $R \& D$ active, and they are more likely to fall back. They are also significantly less likely to perform $R \& D$ continuously. A similar, though less pronounced pattern is observable for the compound crisis-postcrisis period. The only difference is that the likelihood to become move upward to become occasional R\&D performer does not significantly differ.

As concerns innovation, the patterns are in terms of direction of the coefficients relatively stable over time. Firms in both periods experience an increased hazard to fall back from to lower categories. This holds both for state changes from product and process innovations to product or process innovations as well as from product or process innovations to no-innovating. However, there appears to be some tendency that firms in both periods became more likely to move from no to product or process innovations (though not from product or process to product and process innovations). The net effects of the dynamics, nonetheless, is negative because the increase in the chance to move from no to product or process innovations was much smaller (13.55\% in 20082013 and 31.68\% in 2012-2013) than the increase in the hazard to fall back to no innovations (28.14\% in 2008-2013 and 65.00\% in 2011-2013). Thus in either case, that in dynamics due in both periods will result in lower shares of firms performing $R \& D$ and innovation.

In summary, we there is evidence of a change in behaviour of SMEs towards less (broad) innovation and less (continuous) R\&D taking place in the observation period. 
Table 4: Break points in the transition probabilities

\begin{tabular}{|c|c|c|c|c|}
\hline & $\begin{array}{c}R \& D \\
\text { hazard rate }\end{array}$ & $\begin{array}{l}\text { Innovation } \\
\text { hazard rate }\end{array}$ & $\begin{array}{c}R \& D \\
\text { hazard rate }\end{array}$ & $\begin{array}{l}\text { Innovation } \\
\text { hazard rate }\end{array}$ \\
\hline \multicolumn{5}{|c|}{ SME (1-499) } \\
\hline S1S2 & $0.5087 * * *$ & $0.5559 * * *$ & $0.5252 * * *$ & $0.5780 * * *$ \\
\hline S2S1 & $0.8254 * * *$ & $1.2688 * * *$ & $0.8840 * * *$ & $1.3649 * * *$ \\
\hline S2S3 & $0.7863 * * *$ & $0.8190 * * *$ & $0.7632 * * *$ & $0.7833 * * *$ \\
\hline S3S2 & $2.2984 * * *$ & $2.3844 * * *$ & $2.2793 * * *$ & $2.4175 * * *$ \\
\hline \multicolumn{5}{|c|}{ SME (1-499)*Y08-13 } \\
\hline S1S2 & 1.0315 & $1.1355 * * *$ & & \\
\hline S2S1 & $1.1578 * * *$ & $1.2815 * * *$ & & \\
\hline S2S3 & $0.9151 * * *$ & $0.9146 * * *$ & & \\
\hline S3S2 & 0.9943 & $1.1122 * * *$ & & \\
\hline \multicolumn{5}{|c|}{ SME (1-499)*Y11-13 } \\
\hline S1S2 & & & $0.8633 * * *$ & $1.3168 * * *$ \\
\hline S2S1 & & & $1.1264 * * *$ & $1.6500 * * *$ \\
\hline S2S3 & & & $0.8488 * * *$ & 1.0090 \\
\hline S3S2 & & & $1.0335 * * *$ & $1.4561 * * *$ \\
\hline \multicolumn{5}{|c|}{ Med.-high-tec man. } \\
\hline S1S2 & $2.1224 * * *$ & $1.7813 * * *$ & $2.1242 * * *$ & $1.7887 * * *$ \\
\hline S2S1 & $0.6155 * * *$ & $0.5735 * * *$ & $0.6174 * * *$ & $0.5759 * * *$ \\
\hline S2S3 & 1.0536 & 1.0084 & 1.0511 & 1.0104 \\
\hline S3S2 & $0.5001 * * *$ & $0.7046 * * *$ & $0.5001 * * *$ & $0.7083 * * *$ \\
\hline \multicolumn{5}{|c|}{ Med. low-tech. Man. } \\
\hline S1S2 & $1.3278 * * *$ & $1.2436 * * *$ & $1.3292 * * *$ & $1.2465 * * *$ \\
\hline S2S1 & $0.7271 * * *$ & $0.9149 * * *$ & $0.7292 * * *$ & $0.9196 * * *$ \\
\hline S2S3 & $0.8894 * * *$ & 1.0316 & $0.8867 * * *$ & 1.0331 \\
\hline S3S2 & 0.9744 & $0.9074 * * *$ & 0.9741 & $0.9131 * * *$ \\
\hline $\mathrm{N}$ & 144891 & 183774 & 144891 & 183774 \\
\hline $\mathrm{T}$ & 13 & 13 & 13 & 13 \\
\hline LR-test & 80158.86 *** & $10266.82 * * *$ & 80160.09 *** & $10389.48 * * *$ \\
\hline
\end{tabular}

Finally, we consider whether there are any angles for policy to mitigate these negative trends. We have argued in Section 2 that the subsidiaries for innovation and R\&D can serve this purpose. We also posited that two major restraining factors financial restrictions and a lack of internal competences which could be compensated through innovation cooperation. Because in particular, in program support both lacks can potentially be addressed e.g. through cooperation requirements or through additional credit support, we treat these variables as potential angles for policy.

We summarise the results for $R \& D$ in Table 5 , where we first treat each variable in a separate model and then analyse them jointly as a robustness check. The results for subsidies and innovation cooperation are quite consistent. Both increase the likelihood to move to occasional $\mathrm{R} \& \mathrm{D}$ (with a $197 \%$ increase for cooperation) and they reduce the risk to fall back to lower levels (e.g. 67\% lower risk to fall back from continuous to occasional R\&D for cooperation and $46 \%$ for to subsidies). Some effects also emerge for 
financial strength as measured by a credit rating index. This works, however, also for the top end of the R\&D activities, while it does not seem to affect the decision to be either non R\&D-active vs. occasional R\&D performer.

Table 5: Firm characteristics affecting the transition probabilities (R\&D)

\begin{tabular}{|c|c|c|c|c|}
\hline & $\begin{array}{c}R \& D \\
\text { harzard rate }\end{array}$ & $\begin{array}{c}R \& D \\
\text { harzard rate }\end{array}$ & $\begin{array}{c}R \& D \\
\text { harzard rate }\end{array}$ & $\begin{array}{c}R \& D \\
\text { harzard rate }\end{array}$ \\
\hline \multicolumn{5}{|c|}{ SME (1-499) } \\
\hline S1S2 & $0.5688 * * *$ & $0.6591 * * *$ & $0.5259 * * *$ & $0.6541 * * *$ \\
\hline S2S1 & 1.0187 & $0.8868 *$ & 0.9022 & 0.9217 \\
\hline S2S3 & $0.7266 * * *$ & $0.7617 * * *$ & $0.7645 * * *$ & $0.7394 * * *$ \\
\hline S3S2 & $2.2790 * * *$ & $1.9420 * * *$ & $2.1893 * * *$ & $1.9030 * * *$ \\
\hline \multicolumn{5}{|c|}{ Subsidies received } \\
\hline S1S2 & $1.4524 * * *$ & & & $1.1198 * * *$ \\
\hline$S 2 S 1$ & $0.6828 * * *$ & & & $0.7668 * * *$ \\
\hline S2S3 & 0.9833 & & & 1.0064 \\
\hline S3S2 & $0.5395 * * *$ & & & $0.6581 * * *$ \\
\hline \multicolumn{5}{|c|}{ Innovation cooperations } \\
\hline S1S2 & & $2.9734 * * *$ & & $2.7704 * * *$ \\
\hline S2S1 & & $0.5831 * * *$ & & $0.7112 * * *$ \\
\hline S2S3 & & 0.9391 & & $0.8476 * * *$ \\
\hline S3S2 & & $0.3281 * * *$ & & $0.4560 * * *$ \\
\hline \multicolumn{5}{|c|}{ Credit rating } \\
\hline S1S2 & & & 0.9630 & 0.8864 \\
\hline$S 2 S 1$ & & & 0.9275 & $0.8368 * *$ \\
\hline S2S3 & & & $1.1873 * *$ & 1.0709 \\
\hline S3S2 & & & $0.7131 * * *$ & $0.6486 * * *$ \\
\hline \multicolumn{5}{|c|}{ Med. high-tech. man. } \\
\hline S1S2 & $1.9238 * * *$ & $1.9845 * * *$ & $2.1259 * * *$ & $1.8894 * * *$ \\
\hline S2S1 & $0.6235 * * *$ & $0.6494 * * *$ & $0.6166 * * *$ & $0.6448 * * *$ \\
\hline S2S3 & $0.9038 *$ & 0.9977 & 1.0635 & 0.9106 \\
\hline S3S2 & $0.4481 * * *$ & $0.4856 * * *$ & $0.5091 * * *$ & $0.4699 * * *$ \\
\hline \multicolumn{5}{|c|}{ Med. low-tech. man. } \\
\hline S1S2 & $1.2752 * * *$ & $1.2718 * * *$ & $1.3243 * * *$ & $1.2661 * * *$ \\
\hline S2S1 & $0.7114 * * *$ & $0.6807 * * *$ & $0.7286 * * *$ & $0.7032 * * *$ \\
\hline S2S3 & $0.7466 * * *$ & $0.8126 * * *$ & $0.8962 * * *$ & $0.7431 * * *$ \\
\hline S3S2 & $0.7374 * * *$ & $0.8273 * * *$ & 0.9885 & $0.7266 * * *$ \\
\hline$\overline{\mathrm{N}}$ & 100152 & 109906 & 125962 & 98071 \\
\hline $\mathrm{T}$ & 13 & 13 & 13 & 13 \\
\hline LR test & $116006.80 * * *$ & $105354.80 * * *$ & $81035.66 * * *$ & $119480.90 * * *$ \\
\hline
\end{tabular}

If we consider these variables simultaneously, effects are largely corroborated with some notable differences. First, the effect of public subsidies is somewhat attenuated, though still significant. This is most likely due to the fact that subsidies in Germany put great emphasis on cooperative project applications. This means that some of the predictive power of the subsidies actually pertained to the implied increase in cooperative propensity. Second, although the cooperation variable largely behaves as before, there emerges a somewhat puzzling effect indicating a lower likelihood to move from occasional to continuous R\&D. It is unclear whether this resembles something structural as concerns cooperation and $R \& D$, or whether this is simply due to multicollinearity be- 
tween subsidies and the cooperation variable. Third, in this model the effect of better credit ratings seems mainly in reducing the chances of discontinuing $R \& D$ at any level of activity. In any case, it shows that also financial constraints play a role for the dynamics of R\&D activities.

Table 6: Firm characteristics affecting the transition probabilities (innovation)

\begin{tabular}{|c|c|c|c|c|}
\hline & $\begin{array}{l}\text { Innovation } \\
\text { hazard rate }\end{array}$ & $\begin{array}{l}\text { Innovation } \\
\text { hazard rate }\end{array}$ & $\begin{array}{l}\text { Innovation } \\
\text { hazard rate }\end{array}$ & $\begin{array}{l}\text { Innovation } \\
\text { hazard rate }\end{array}$ \\
\hline \multicolumn{5}{|c|}{ SME (1-499) } \\
\hline S1S2 & $0.6142 * * *$ & $0.6712 * * *$ & $0.5480 * * *$ & $0.6276 * * *$ \\
\hline$S 2 S 1$ & $1.3820 * * *$ & $1.2588 * * *$ & $1.3285 * * *$ & $1.1879 * * *$ \\
\hline S2S3 & $0.7774 * * *$ & $0.8014 * * *$ & $0.8108 * * *$ & $0.8165 * * *$ \\
\hline S3S2 & $2.5450 * * *$ & $2.3027 * * *$ & $2.4425 * * *$ & $2.2678 * * *$ \\
\hline \multicolumn{5}{|c|}{ Subsidies received } \\
\hline S1S2 & $1.5535 * * *$ & & & $1.2564 * * *$ \\
\hline S2S1 & $0.7171 * * *$ & & & $0.8243 * * *$ \\
\hline S2S3 & 1.0292 & & & 0.9774 \\
\hline S3S2 & $0.7736 * * *$ & & & $0.8479 * * *$ \\
\hline \multicolumn{5}{|c|}{ Innovation cooperations } \\
\hline S1S2 & & $2.2914 * * *$ & & $1.8278 * * *$ \\
\hline$S 2 S 1$ & & $0.5005 * * *$ & & $0.5841 * * *$ \\
\hline S2S3 & & $1.0872 * * *$ & & 1.0075 \\
\hline S3S2 & & $0.5776 * * *$ & & $0.6092 * * *$ \\
\hline \multicolumn{5}{|c|}{ Credit rating } \\
\hline S1S2 & & & 1.0736 & $1.1594 * * *$ \\
\hline S2S1 & & & $0.9207 *$ & $0.9340 *$ \\
\hline S2S3 & & & 1.0908 & 1.0448 \\
\hline S3S2 & & & $0.7966 * *$ & $0.7539 * * *$ \\
\hline \multicolumn{5}{|c|}{ Med. high-tech. man. } \\
\hline S1S2 & $1.6240 * * *$ & $1.5976 * * *$ & $1.8410 * * *$ & $1.5711 * * *$ \\
\hline S2S1 & $0.6560 * * *$ & $0.6406 * * *$ & $0.5880 * * *$ & $0.6975 * * *$ \\
\hline S2S3 & 0.9418 & 0.9857 & 1.0299 & 0.9373 \\
\hline S3S2 & $0.7028 * * *$ & $0.7424 * * *$ & $0.7212 * * *$ & $0.7318 * * *$ \\
\hline \multicolumn{5}{|c|}{ Med. low-tech. man. } \\
\hline S1S2 & $1.2180 * * *$ & $1.2285 * * *$ & $1.2729 * * *$ & $1.2338 * * *$ \\
\hline S2S1 & $0.8974 * * *$ & $0.8855 * * *$ & $0.9295 * * *$ & $0.9141 * * *$ \\
\hline S2S3 & 1.0178 & 1.0291 & 1.0527 & 1.0444 \\
\hline S3S2 & $0.8999 * * *$ & $0.8925 * * *$ & $0.9157 * * *$ & $0.9031 * * *$ \\
\hline $\mathrm{N}$ & 145338 & 157999 & 149200 & 116761 \\
\hline $\mathrm{T}$ & 13 & 13 & 13 & 13 \\
\hline LR-test & $61347.99 * * *$ & $44937.60 * * *$ & $28782.43 * * *$ & $77627.45 * * *$ \\
\hline
\end{tabular}

When turning to innovation (Table 6) we observe a roughly consistent measure for all three variables. In terms of direction, no differences appear for subsidies, which increase the likelihood to move upward to occasional R\&D and reduce the risks of falling back to lower categories. Also here cooperation seems to very effective, which additionally increases the chances to move upward to continuous R\&D strategy. Positive effects can also be discerned for the credit rating. If considered simultaneously, the re- 
sults remain robust. The only effect that disappears is the increase in the likelihood to become a simultaneous product and process innovator as implied by collaboration activities.

\section{Conclusion}

Persistence is major characteristics of innovation and R\&D processes in firms. This can result from path-dependent learning, sunk costs, or strategic commitment. However, despite the general feature of persistence descriptive accounts of level and distribution of innovation expenditures have demonstrated a strong concentration on large firms. SMEs seem to have retracted from innovation and R\&D to some degree. In this paper we took these descriptive phenomena as the starting point and analysed these trends in a multivariate Markov Chain modelling approach. Our results indeed confirm the descriptive statistics and show that even after controlling for firm potentially confounding changes in the sector composition or innovation-induced growth processes the share of non-innovation/R\&D-active firms have considerably increased. Likewise, the stationary distributions indicate that the share of continuous $R \& D$ performers and the share of simultaneous product and process innovators decreased by about a third in the study period from 2001 to 2013. We also showed that that these trends are rather permanent changes than transitory shocks induced by the economic crisis in 2008/09. This is particularly problematic because persistence in innovation strategies suggests that a firm's decision to move out of innovation and $R \& D$ cannot be easily undone. This is because of the cumulative nature of innovation processes. In particular, firms discontinuing innovation and R\&D tend to loose the capabilities associated with these activities. Thus, even if the retraction from innovation activities may in short-run save costs, in the longer term established market positions will erode, if firms to not continuously improve their products and production processes. While this may be a long and drawn-out process, the greatest danger is that firms may not find it easy to restart their innovation activities, because they lack the necessary competences (Dosi 1996). Thus there is a danger that firms withdrawing from innovation experience their established positions to 
gradually wither while they are unable to perform renewal processes that could counteract these trends.

Beyond the corroboration of the descriptive findings, we also provided evidence that this concentration trend is the result of the retraction of mainly smaller firms. While Germany is often hailed for its highly innovative SME sector, this suggests that the German innovation system is gradually loosing one of its most important pillars. This can in the long-run bear considerable systemic risks not only for smaller firms themselves but also for the larger ones. In particular, several authors have highlighted the existence of complementarity between small and large firms in innovation (Nooteboom 1999; Tether 1998; Belderbos et al. 2006; Nooteboom 2009) that often results from a greater organizational flexibility and flat hierarchies of smaller firms (Baier et al. 2013). In particular, in high-tech sectors large “outsource” parts of their innovation activities to innovation alliances with smaller firms experiencing a lower degree of organizational rigidity (Ciborra 1991). However, if such innovation active SMEs become increasingly scarce, the potentials using the organizational complementarities in innovation vanish.

A further problem of the concentration is related to the hazard of Germany developing and industrial monoculture dominated by a few large firms. More precisely, if only a limited number of firms mainly located in some key sectors (automobiles, chemistry, and machine construction), there is a risk that the sector composition in Germany will shift even more to towards these selected factors. This is because the effect of innovation is one of creating an asymmetry by making some firms more competitive than others (Dosi 1988). The more competitive firms will then grow at the expense of other firms. On the sector level this will imply a shift of resources to sectors with higher levels of innovativeness (Andries et al. 2015). While the reallocation of resources towards more productive uses is certainly desirable, the fact that only a limited number of firms are driving this trend, this implies an increasing dependence on few firms and sectors. As a consequence the German economy runs a risk of becoming much more vulnerable to aggregate technology or demand side shocks that affect firms in a certain sector in a similar way. In this respect, the ongoing concentration processes may in the longer term 
considerably reduce the resilience of the German economy against crises and business cycles.

Thus from a policy perspective, there is therefore a strong need to take measures against the concentration of innovation and R\&D activities on larger. Our results showed that several firm characteristics considerably moderate the decisions to move in or out of innovation and R\&D. We have found that public subsidies, innovation cooperation, and better financial positions tend to be associated with lower risks of falling back to lower levels of innovation and $R \& D$ engagement while they increase the chances that firms increase their innovation and R\&D engagement. As concerns public subsidies this emphasises the effectiveness of the existing project support in Germany to keep firms committed to innovation and R\&D activities. Indeed, there is considerable potential to increase the state support still, as Germany is among the countries with the lowest shares of state-funded enterprise R\&D. More specifically, in 2012 this share was slightly above $4 \%$ in Germany, while it was almost $8 \%$ in France and the UK and more than $10 \%$ in the US. Even Italy, heavily hit by financial crisis, ranked much higher with about 7\% (Deutsche Telekomstiftung 2014). The beneficial effects of innovation cooperation and higher financing capabilities give an indication of the mechanisms through which the public innovation and R\&D support works. In specific, it is commonly argued that project support has at least two beneficial effects. First, it allocates financial resources to firms and therefore increases the internal financing capabilities. It may also serve as a signal to external financing institutions and therefore may facilitate the access to debt financing or the capital markets. Second, the innovation project support is regularly organised in cooperative projects, which is a further contribution factor to staying committed to innovation processes. This may result both from knowledge complementarities between the partners (Harrigan 1988; Parkhe 1993; Schubert 2015) or from stable institutionalised frameworks for innovation projects (Rammer et al. 2013). Accordingly, Rammer et al. (2013) provide empirical evidence that up to $40 \%$ of the total effect of public support may be attributable to the fact that these programs require collaborative projects. 
While this underlines the general benefits of subsidizing collaborative innovation projects, Rammer et al. (2013) also emphasise that selection process in public innovation support tends to disadvantage outsiders and newcomers. Accordingly, Peters (2009) provide evidence that innovation subsidies tend to become persistent creating funding careers. Having received funding in the past tends to causally increase the chances of receiving further funding. A concentration of funds on firms with proven track records of successful projects may statically be efficient because the expected output is maximised. At the same time it ostracises firms with little or no funding experience. However, if the goal is to increase the share of innovators or R\&D performers, then such an allocation is likely to be problematic, because it does little to support innovation newcomers. Thus, there is a need to find support schemes that are tailored towards firms with little prior innovation and $R \& D$ engagement. Rather than the maximizing outputs per funding volume in the short run the justification would be to enlarge the base of innovation active firms in the economy. Schemes that could contribute to this objective could be implemented in several ways. One alternative is to create project support schemes that are open only for innovation newcomers. A second alternative are unconditional tax subsidies for $R \& D$ and innovation. Comprehensive empirical evidence from different countries and time periods has shown that these tax credits can be effective in raising R\&D expenditures (Hall 1993; Bloom et al. 2002; Czarnitzki et al. 2011).

\section{References}

Alfranca, O., R. Rama, N. von Tunzelmann (2002), A patent analysis of global food and beverage firms: the persistence of innovation, Agribusiness 18(3), 349-368.

Andries, P., M. Hoskens, J. Janger, C. Rammer, T. Schubert (2015), The New EU 2020 Innovation Indicator: A Step Forward in Measuring Innovation Output? Concordi Conference, Sevilla.

Antonelli, C., F. Crespi, G. Scellato (2012), Inside innovation persistence: new evidence from Italian micro-data, Structural Change and Economic Dynamics 23(4), 341353. 
Antonelli, C., F. Crespi, G. Scellato (2013), Internal and external factors in innovation persistence, Economics of Innovation and New Technology 22(3), 256-280.

Aschhoff, B., E. Baier, D. Crass, M. Hud, P. Hünermund, C. Köhler, B. Peters, C. Rammer, E. Schricke, T. Schubert, F. Schwiebacher (2013), Innovation in Germany - Results of the German CIS 2006 to 2010, ZEW Documentation 13-01, Mannheim.

Baier, E., C. Rammer, T. Schubert (2015), The impact of captive innovation offshoring on the effectiveness of organizational adaptation, Journal of International Management 21, 150-165.

Baraldi, A.L., C. Cantabene, G. Perani (2013), Reverse Causality in the R\&D-Patents Relationship: An Interpretation of the Innovation Persistence, mimeo, University of Naples.

Belderbos, R., M. Carree, B. Lokshin (2006), Complementarity in R\&D cooperation strategies, Review of Industrial Organization 28, 401-426.

Bloom, N., R. Griffith, J. van Reenen (2002), Do R\&D tax credits work? Evidence from a panel of countries 1979-1997, Journal of Public Economics 85, 1-31.

Bottazzi, G., G. Dosi, G. Rocchetti (2001), Modes of knowledge accumulation, entry regimes and patterns of industrial evolution, Industrial and Corporate Change 10, 609-638.

Cefis, E. (2003), Is there persistence in innovative activities? International Journal of Industrial Organization 21, 489-515.

Cefis, E., K. Orsenigo (2001), The persistence of innovative activities. A crosscountries and cross-sectors comparative analysis, Research Policy 30, 1139-1158.

Ciborra, C.U. (1991), From Thinking to Tinkering: The Grassroots of Strategic Information Systems, Proceedings of the Twelfth International Conference on Information Systems, New York, 283-291. 
Clausen, H., M. Pohjola (2013), Persistence of product innovation: comparing breakthrough and incremental product innovation, Technology Analysis \& Strategic Management 25(4), 369-385.

Clausen, T., M. Pohjola, K. Sappraserty., B. Verspagen (2012), Innovation strategies as a source of persistent innovation, Industrial and Corporate Change 21(3), 553585.

Cohen, W., D. Levinthal (1990), Absorptive capacity: a new perspective on learning and innovation, Administrative Science Quarterly 35(1), 128-158.

Colombelli, A., F. Quatraro (2014), The persistence of firms' knowledge base: a quantile approach to Italian data, Economics of Innovation and New Technology 23(7), 585-610.

Crespi, F., G. Scellato (2015), Knowledge cumulability and path dependence in innovation persistence, in: C. Antonelli, A.N. Link (eds.), Routledge Handbook of the Economics of Knowledge, New York: Routledge, 116-134.

Czarnitzki, D., P. Hanel, J.M. Rosa (2011), Evaluating the impact of R\&D tax credits on innovation: a microeconometric study on Canadian firms, Research Policy 40, 217-229.

Deschryvere, M. (2014), R\&D, firm growth and the role of innovation persistence: an analysis of Finnish SMEs and large firms, Small Business Economics 43, 767785.

Deutsche Telekomstiftung (ed.) (2014), Innovationsindikator 2014, Bonn.

Dosi, G. (1988), Sources, procedures, and microeconomic effects of innovation, Journal of Economic Literature 26, 1120-1171.

Dosi, G. (2007), Statistical regularities in the evolution of industries - a guide through some evidence and challenges for the theory, in: F. Malerba, S. Brusoni (eds.), Perspectives on Innovation, Cambridge: Cambridge University Press, 152-186. 
Duguet, E., S. Monjon (2002), Creative Destruction and the Innovative Core: Is Innovation Persistent at the Firm Level? An Empirical Examination from CIS Data Comparing the Propensity Score and Regression Methods, Discussion Papers in Economics 02-07, University College London.

Duguet, E., S. Monjon (2004), Is Innovation Persistent at the Firm Level? An Econometric Examination Comparing the Propensity Score and Regression Methods, mimeo, University of Paris I.

Flaig, G., M. Stadler (1994), Success breeds success. The dynamics of the innovation process, Empirical Economics 19(1), 55-68.

Ganter, A., A. Hecker (2013), Persistence of innovation: discriminating between types of innovation and sources of state dependence, Research Policy 42, 1431-1445.

Geroski, P.A., J. van Reenen, C.F. Walters (1997), How persistently do firms innovate? Research Policy 26, 33-48.

Hall, B.H. (1993), R\&D tax policy during the 1980s: success or failure?, in: J. Poterba (ed.), Tax Policy and the Economy, Volume 7, Cambridge, Ma.: MIT Press, 1-36.

Haned, N., C. Mothe, T.U. Nguyen-Thi (2014), Firm persistence in technological innovation: the relevance of organizational innovation, Economics of Innovation and New Technology 23(5-6), 490-516.

Harrigan, K.R. (1988), Strategic alliances and partner asymmetries, in: F. Contractor, P. Lorange (eds.), Cooperative Strategies in International Business, Lexington, MA: Lexington Books, 53-73.

Hecker, A., A. Ganter (2014), Path and past dependence of firm innovation, Economics of Innovation and New Technology 23(5-6), 563-583.

Huang, C.H. (2008), A note on the persistence of firms' innovation behavior: a dynamic random effect probit model approach, Economics Bulletin 15(5), 1-9. 
Huang, C.-H., C.-H. Yang (2010), Persistence of innovation in Taiwan’s manufacturing firms, Taiwan Economic Review 38(2), 199-231.

Jang, S.-L., J. H. Chen (2011), What determines how long an innovative spell will last? Scientometrics 86(1), 65-76.

Johansson, B., H. Lööf (2010), Innovation Strategy and Firm Performance - What is the Long-run Impact of Persistent R\&D? CESIS Electronic Working Paper Series 240, Royal Institute of Technology, Stockholm.

Karlsson, C., S. Tavassoli (2015), Persistence of Various Types of Innovation Analysed and Explained, CESIS Electronic Working Paper Series No. 392, Royal Institute of Technology, Stockholm.

Latham, W., C. Le Bas (2006), The Economics of Persistent Innovation: An Evolutionary View, Berlin: Springer.

Le Bas, C., C. Mothe, T.U. Nguyen (2015), The differentiated impacts of organizational innovation practices on technological innovation persistence, European Journal of Innovation Management 18(1), 110-127.

Le Bas, C., G. Scellato (2014), Firm innovation persistence: a fresh look at the frameworks of analysis, Economics of Innovation and New Technology 23(5-6), 423446.

Le Bas, C., N. Poussing (2014), Are complex innovators more persistent than single innovators? An empirical analysis of innovation persistence drivers, International Journal of Innovation Management 18(1), no paging (DOI: 10.1142/S136391961450008X).

Lhuillery, S. (2014), Marketing and persistent innovation success, Economics of Innovation and New Technology 23(5-6), 517-543.

Malerba, F., L. Orsenigo (1999), Technological entry, exit and survival: an empirical analysis of patent data, Research Policy 28(6), 643-660. 
Malerba, F., L. Orsenigo, P. Peretto (1997), Persistence of innovative activities, sectoral patterns of innovation and international technological specialization, International Journal of Industrial Organization 15, 801-826.

Máñez Castillejo, J.A., M.E. Rochina Barrachina, A. Sanchis Llopis, J.A. Sanchis Llopis (2004), A Dynamic Approach to the Decision to Invest in R\&D: The Role of Sunk Costs, mimeo, University of Valencia.

Máñez Castillejo, J.A., M.E. Rochina Barrachina, A. Sanchis Llopis, J.A. Sanchis Llopis (2009), The role of sunk costs in the decision to invest in R\&D, Journal of Industrial Economics 57(4), 712-735.

Máñez, J.A., M.E. Rochina-Barrachina, A. Sanchis-Llopis, J.A. Sanchis-Llopis (2014), The determinants of R\&D persistence in SMEs, Small Business Economics 44, 505-528.

Mansfield, E. (1968), Industrial Research and Technological Innovation: An Econometric Analysis, New York: Norton.

Martínez-Ros, E., J.M. Labeaga (2009), Product and process innovation: persistence and complementarities, European Management Review 6(1), 64-75.

Matvejeva, A. (2014), Determinants of persistence in innovation: evidence from the case study of the 'Eye Microsurgery' complex, Economics of Innovation and New Technology 23(5-6), 544-562.

Napoli, R. (2008), Innovation in the financial sector: persistence and Schumpeterian hypotheses - econometric evidence in Germany, Journal of Service Science and Management 1(3), 215-226.

Nelson, R., S. Winter (1982), An Evolutionary Theory of Economic Change, Cambridge: Belknap Press.

Neuhäusler, P. (2012), The use of patents and informal appropriation mechanisms differences between sectors and among companies, Technovation 32, 681-693. 
Nooteboom, B. (1999), Innovation, learning and industrial organisation, Cambridge Journal of Economics 23, 127-150.

Nooteboom, B. (2009), A Cognitive Theory of the Firm: Learning, Governance and Dynamic Capabilities, Cheltenham: Edward Elgar.

Parkhe, A. (1993), The structuring of strategic alliances: a game theoretic and transaction-cost examination of interfirm cooperation. Academy of Management Journal 36, 794-829.

Peters, B. (2009), Persistence of innovation: stylised facts and panel data evidence, Journal of Technology Transfer 34, 226-243.

Phillips, A. (1971), Technology and Market Structure: A Study of the Aircraft Industry, Lexington: Heath Lexington Books.

Prevezer M., M. Frenz (2013), What can CIS data tell us about technological regimes and persistence of innovation? Industry and Innovation 19(4), 285-306.

Rammer, C., B. Peters (2013), Innovation Panel Surveys in Germany, in: F. Gault (ed.), Handbook of Innovation Indicators and Measurement, Cheltenham and Northampton, Ma.: Edward Elgar, 135-177.

Rammer, C., O. Som, S. Kinkel, C. Köhler, T. Schubert, F. Schwiebacher, E. Kirner, A. Pesau, M. Murmann (2012), Innovationen ohne Forschung, ZEW Wirtschaftsanalysen, Bd. 101, Baden-Baden: Nomos.

Raymond, W., P. Mohnen, F.C. Palm, S. Schim van der Loeff (2010), Persistence of innovation in Dutch manufacturing: is it spurious? Review of Economics and Statistics 92(3), 495-504.

Rogers, M. (2004), Networks, firm size and innovation, Small Business Economics 22(2), 141-153. 
Roper, S., N. Hewitt-Dundas (2008), Innovation persistence: survey and case study evidence, Research Policy 37, 149-162.

Schmookler, J. (1966), Invention and Economic Growth, Cambridge, Ma.: Harvard University Press.

Schubert, T. (2015), Infringement of intellectual property in innovation partnerships, $R \& D$ Management, forthcoming (DOI: 10.1111/radm.12128).

Suárez, D. (2014), Persistence of innovation in unstable environments: Continuity and change in the firm's innovative behavior, Research Policy 43, 726-736.

Sutton, J. (1991), Sunk Costs and Market Structure, Cambridge, Ma.: MIT Press.

Tether, B.S. (1998), Small and large firms: sources of unequal innovations? Research Policy 27, 725-745.

Teece, D.J. (1986), Profiting from technological innovation: implications for integration, collaboration, licensing and public policy, Research Policy 15, 285-305.

Teece, R., G. Pisano, A. Shuen (1997), Dynamic capabilities and strategic management, Strategic Management Journal 18, 509-533.

Triguero, A., D. Córcoles (2013), Understanding the innovation: an analysis of persistence for Spanish manufacturing firms, Research Policy 42(2), 340-352.

Triguero, A., D. Córcoles, M.C. Cuerva (2014a), Persistence of innovation and firm’s growth: evidence from a panel of SME and large Spanish manufacturing firms, Small Business Economics 43, 787-804.

Triguero, A., D. Córcoles, M.C. Cuerva (2014b), Measuring the persistence in innovation in Spanish manufacturing firms: empirical evidence using discrete-time duration models, Economics of Innovation and New Technology 23(5-6), 447-468.

Woerter, M. (2014), Competition and persistence of R\&D, Economics of Innovation and New Technology 23(5-6), 469-489. 
